\section{OSU 663, OSU 668, and OSU 677 Pea Breeding Lines Resistant to Pea Seedborne Mosaic Virus}

\author{
James R. Baggett and Kathryn Kasimor \\ Department of Horticulture, Oregon State University, Agricultural and Life \\ Sciences Building 4017, Corvallis, OR 97331-7304
}

\section{Richard O. Hampton}

U.S. Department of Agriculture, Agricultural Research Service, Department of Botany and Plant Pathology, Oregon State University, Corvallis, OR 97331

Additional index words. Pisum sativum, vegetable breeding
Resistance to pea seedborne mosaic virus (PSbMV) has become an objective of many commercial and public pea (Pisum sativum L.) breeding programs. Cultivar resistance should relieve the pea seed industry of the restrictions and expense involved in avoiding PSbMV contaminated seed. Resistance sources have been identified (Baggett and Hampton, 1972; Stevenson and Hagedorn, 1971) and breeding lines have been released from earlier cycles of the Oregon State Univ. (OSU) breeding program (Baggett and Hampton, 1977; Baggett and Kean, 1988). The OSU breeding program is directed primarily toward resistance to PSbMV pathotype $\mathrm{P}_{1}$ (PSbMV-P), but advanced lines have also been screened for resistance to PSbMV-lentil strain (PSbMV-L) (Alconero et al., 1986).

OSU 663, OSU 668, and OSU 677 are pea breeding lines that were released in 1990 by the Oregon Agricultural Experiment Station as sources of combined resistance to PSbMV and pea enation mosaic virus (PEMV). These three lines were selected from among available material because they provide combined PSbMV and PEMV resistance in three important types of peas: freezing (shelling) peas (OSU 663), snap peas (OSU 668), and edible pod (Oriental) pea (OSU 677). They were developed as part of a continuing OSU disease-resistant pea breeding program. The stability of the PSbMV-P resistance of these immunosorbent assay (ELISA) method.

\section{Origin}

OSU 663 is a bulk of several indistinguishable daughter lines of an $\mathrm{F}_{6}$ line from OSU 547-29 x OSU 695. Resistance to PSbMV-P

Received for publication 10 May 1993. Accepted for publication 27 Oct. 1993. Oregon Agricultural Experiment Station Technical Paper no. 10,218. The cost of publishing this paper was defrayed in part by the payment of page charges. Under postal regulations, this paper therefore must be hereby marked advertisement solely to indicate this fact. lines was verified using the enzyme-linked in OSU 547-29, previously released as a breeding line (Baggett and Kean, 1988), was derived from PI 193586 (Fig. 1). Released as home garden cultivar Oregon Trail (Baggett and Kean, 1992), OSU 695 was the source of improved type and powdery mildew resistance (Erysiphe polygoni DC). Both parents are resistant to PEMV.

OSU 668 is an $\mathrm{F}_{6}$ selection from OSU 584-16 × 'Sugarbon'. In this cross, PSbMV- ${ }_{1}$ and PEMV resistance came from previously released OSU 584-16 (Baggett and Kean, 1988). The original source of PSbMV- $\mathrm{P}_{1}$ resistance was PI 269774 (Fig. 1). The snap pea trait and powdery mildew resistance came from 'Sugarbon' (Rogers-NK Seed Co., Boise, Idaho).

OSU 677 is an $\mathrm{F}_{6}$ selection from OSU 621-20 × M193. OSU 621-20 is a PSbMV- $\mathrm{P}_{\text {- }}$ resistant Oriental pea, and M193 is a PEMVand powdery-mildew-resistant OSU Oriental pea breeding line derived from 'Oregon Sugarpod II' (Baggett, 1982). The original source of PSbMV-P resistance was PI 193586 (Fig. 1).

\section{Descriptions}

OSU 663 is a shelling pea with a short (bush) plant $\approx 60$ to $75 \mathrm{~cm}$ in height. It reaches maturity in midseason, with first pods borne on or about node 15 . The pods, which are borne two per node, are long, straight, and blunt (Fig. 2A). Typical pods are $9.5 \mathrm{~cm}$ long $\times 1.5 \mathrm{~cm}$ wide, bearing up to 10 , but typically nine, dark-green (freezer color) seeds. Pods have a moderate ballooning tendency. We judged this pea to have good flavor.

OSU 668 is a snap (thick-walled, edible pod) pea with a bush plant that typically reaches $76 \mathrm{~cm}$ in height. It reaches maturity in midseason, with pod set beginning on nodes 15-16. The plant has small leaves and bears a heavy pod crop, mostly two per node. The pods (Fig. 2B) have strings and are distinctly curved. Pods are $7.8 \mathrm{~cm}$ long $\times 1.4 \mathrm{~cm}$ wide with average wall thickness for snap peas, and there are usually nine seeds per pod. Pods and seeds are light green (canner color).

OSU 677 is an Oriental pea (flat, edible pod) with a bush plant habit. It reaches matu-
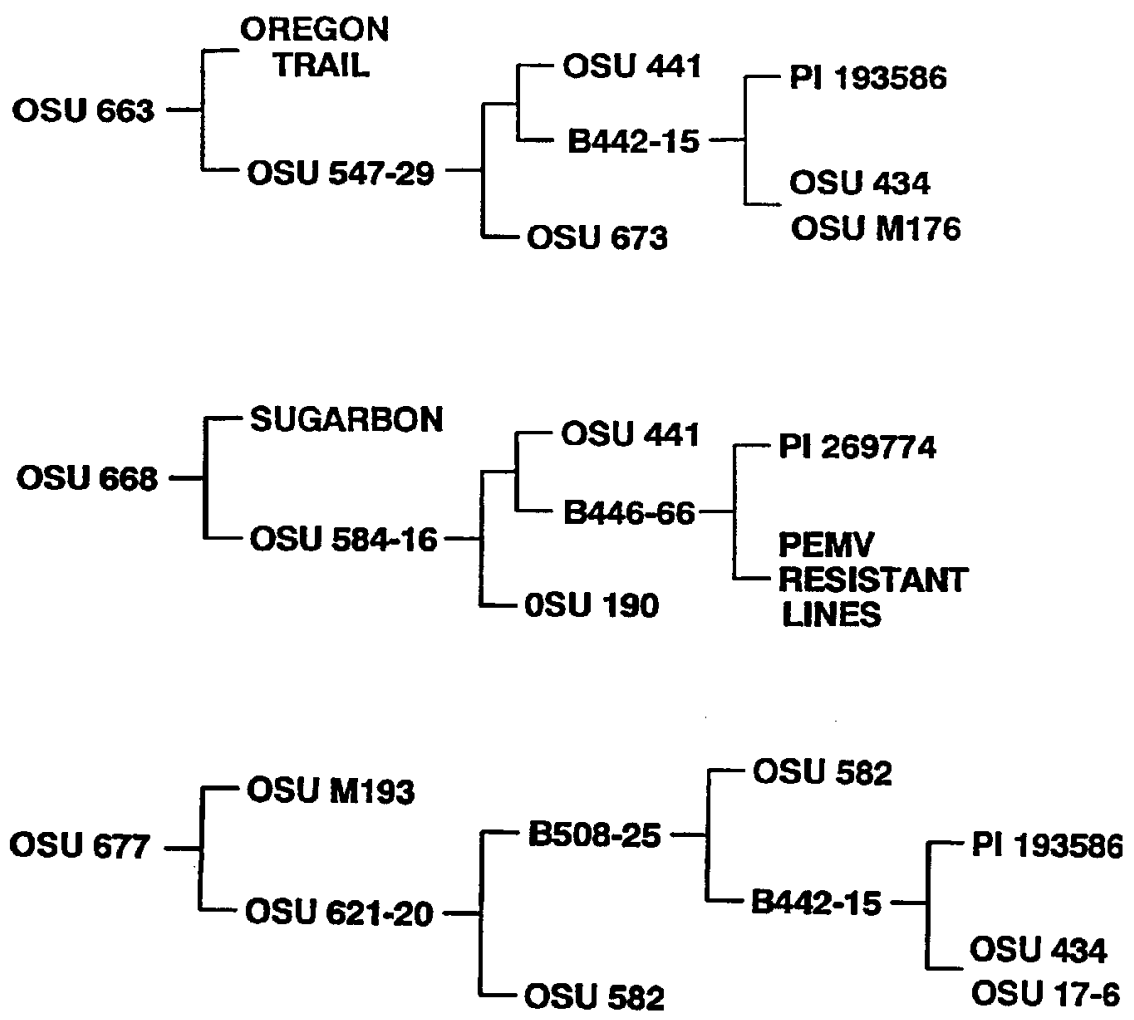

Fig, 1. Pedigrees of OSU 663, OSU 668, and OSU 677 pea lines 
rity in mid- to late season. The plant is typitally $76 \mathrm{~cm}$ in height, usually bearing two pods per node. Pods (Fig. 2C) are $11 \mathrm{~cm}$ long $\times 2.3 \mathrm{~cm}$ wide and bear eight to nine seeds per pod. Pods and seeds are dark green. Because pods sometimes have slight fiber or parch-
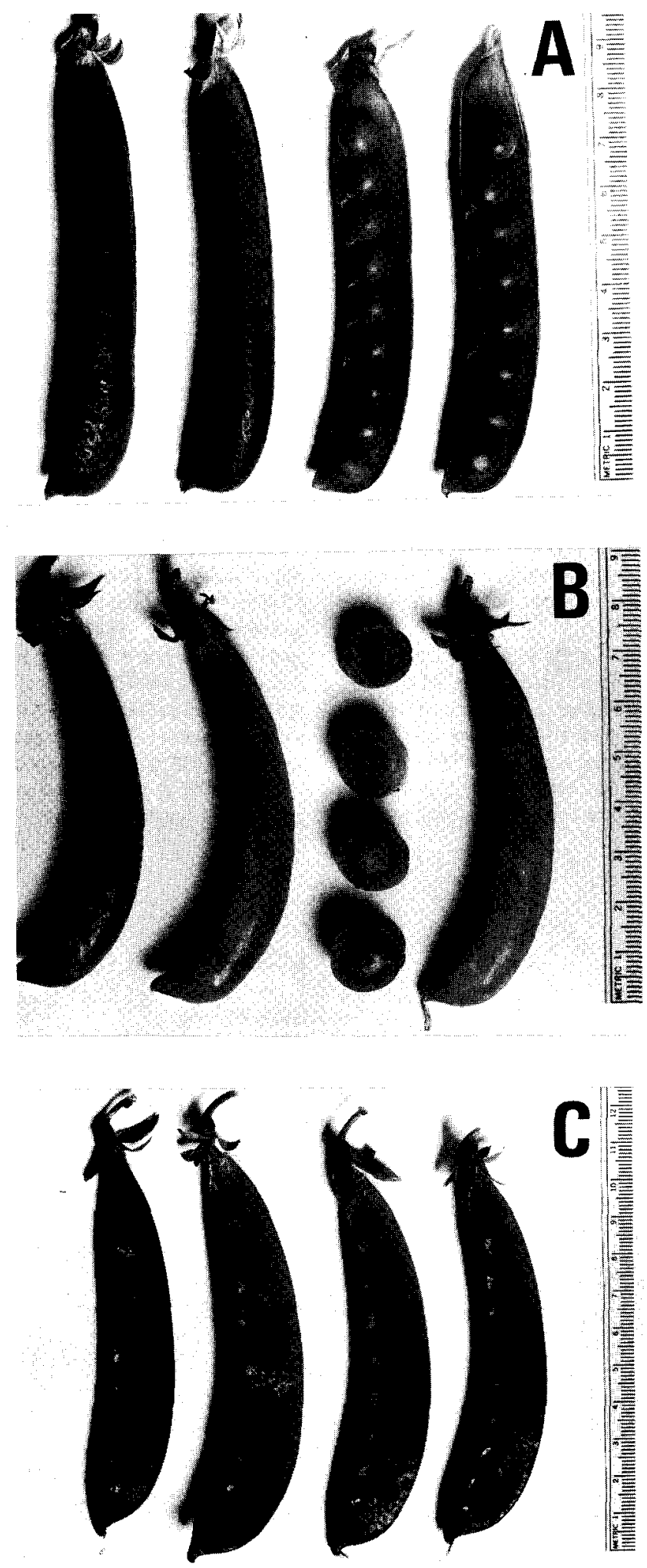

Fig. 2. Pods of (A) OSU 663, (B) OSU 668, and (C) OSU 677 peas at acceptable stages for harvest. ment, OSU 677 should be used in crosses with high-quality Oriental pea parents.

\section{Disease resistance}

All three lines have shown good field resistance to PEMV, powdery mildew, and red clover vein mosaic virus for eight consecutive summers during their development and since their release in 1990. They have also been resistant to common pea wilt [Fusarium oxysporum Schlect. (emend Snyd. and Hans.) f. pisi (Van Hall) Snyd. and Hans. race 1 Snyd.] in field trials conducted at Washington State Univ. from 1989 to 1992.

Resistance to PSbMV-P $\mathrm{P}_{1}$ was determined by mechanical inoculation in greenhouse tests, beginning with screening random $\mathrm{F}_{3}$ families (selected in the field for PEMV resistance) and continuing with new selections each year. During 1984-92, a total of 676 plants of OSU 663,344 plants of OSU 668, and 216 plants of OSU 677 were inoculated with the type strain of PSbMV-P in the greenhouse. Plants suspected of being infected with PSbMV-P, were determined to-be free of detectable infection by back inoculation to 'Sounder' or by ELISA. One infected OSU 677 plant from 1993 inoculations was confirmed positive by ELISA and assumed to be a genetic variant or seed mixture. Susceptible controls mechanically inoculated during 1984-93 were infected at $60 \%$ for 'Sounder' and $86 \%$ for 'Little Marvel'.

In 1990 and 1991, a total of 231 plants of OSU 663,70 plants of OSU 668, and 70 plants of OSU 677 were noninfected after inoculation with PSbMV-L [pathotype $\mathrm{P}_{2}$ (Alconero et al., 1986)].

\section{Availability}

Samples of seed for breeding purposes can be obtained from J.R.B.

\section{Literature Cited}

Alconero, R., R. Provvidenti, and D. Gonsalves. 1986. Three pea seedborne mosaic virus pathotypes from pea and lentil germplasm. Plant Dis. 70:783-786.

Baggett, J.R. 1982. 'Oregon SugarPod II' edible pod pea. HortScience 17:93-94.

Baggett, J.R. and R.O. Hampton. 1972. Plant introduction lines of Pisum sativum resistant to pea fizzletop disease. Plant Dis. Rptr. 56:131-132.

Baggett, J.R. and R.O. Hampton. 1977. Oregon B442-15 and B445-66 pea seedborne mosaic virus-resistant breeding lines. HortScience 12:506.

Baggett, J.R. and D. Kean. 1988. Seven pea seedborne mosaic virus resistant pea breeding lines. HortScience 23:630-631.

Baggett, J.R. and D. Kean. 1992, 'Oregon Pioneer' and 'Oregon Trail' peas. HortScience 27:13341335.

Stevenson, W.R. and D.J. Hagedorn. 1971. Reaction of Pisum sativum to the pea seedborne mosaic virus. Plant Dis. Rptr. 55:408-410. 